\title{
Analisis Video Comments To Video Views Ratio Tiktok Pada 5 Brand Hp Terlaris Di Indonesia Versi Canalys
}

\author{
Rizky Andita \\ andita597@gmail.com
}

\begin{abstract}
Social media is a new place for business people to market their products or do marketing. The TikTok application is a social network and Chinese music video platform launched in September 2016. Tiktok is also a social media application that displays short videos and can be arranged in such a way, where Tiktok is currently being popularly used by various groups of people. Because the TikTok marketing market is considered promising, not a few wellknown brands or vendors are trying to do marketing through TikTok, including the following smartphone brand vendors: Vivo, Oppo, Samsung, Realme and Xiaomi. The purpose of this study is to determine the credibility of the performance of the Canalys version of the 5 Best Selling HP Brand TikTok accounts in Indonesia using Video Comments to Video Views Ratio. The method used in this study is a quantitative exploratory method. The results of this study show that the Xiaomi Indonesia brand gets the highest rating and has the best account performance credibility compared to other brands or vendors.
\end{abstract}

\begin{abstract}
ABSTRAK
Media sosial merupakan tempat baru untuk para pebisnis melakukan pemasaran produk mereka atau melakukan marketing. Aplikasi TikTok adalah sebuah jaringan sosial dan platform video musik Tiongkok yang diluncurkan pada September 2016. Tiktok juga merupakan salah satu aplikasi media sosial yang menampilkan video berdurasi pendek dan dapat diatur sedemikian rupa, dimana Tiktok saat ini sedang popular digunakan oleh berbagai kalangan masyarakat. Karena pasar marketing Tiktok dinilai menjanjikan, tidak sedikit brand atau vendor ternama yang mencoba melakukan pemasaran melalui TikTok diantaranya seperti vendor brand smartphone berikut: Vivo, Oppo, Samsung, Realme dan Xiaomi. Tujuan dari penelitian ini adalah mengetahui kredibilitas performa dari akun TikTok 5 Brand HP Terlaris di Indonesia Versi Canalys menggunakan Video Comments to Video Views Ratio. Metode yang digunakan pada penelitian ini adalah metode eksploratif kuantitatif. Hasil dari penelitian ini menunjukkan brand Xiaomi Indonesia mendapatkan peringkat tertinggi serta memiliki kredibilitas performa akun yang terbaik dibandingkan dengan brand atau vendor lainnya.
\end{abstract}

Keyword : Video Comment to Video Views Ratio; Social Media; TikTok; Brand Smartphone; 


\section{PENDAHULUAN}

Bersosialisasi dan melakukan aktivitas sosial adalah sesuatu yang wajib dilakukan oleh setiap orang sebagai makhluk sosial yang tidak bisa hidup sendiri, apalagi pada zaman seperti sekarang ini, kini sudah muncul berbagai cara untuk kita saling berhubungan sosial atau bersosialisasi dengan orang lain tanpa dipengaruhi kendala jarak, bahasa, waktu, dll. Terlebih dengan adanya smartphone dan media sosial.

Saat ini, media sosial telah menjadi platform pelaporan dan sumber berita utama bagi masyarakat (Eka Putri 2009). Laporan terbaru soal brand handphone (HP) terlaris di Indonesia pada kuartal keempat tahun 2020 cukup mengejutkan. laporan yang dikeluarkan firma riset Canalys itu memperlihatkan persaingan ketat antar brand untuk merebut pangsa pasar smartphone di Indonesia ("5 Brand HP Terlaris Di Indonesia Versi Canalys: Vivo Juara, Samsung Merosot | Kumparan.Com" n.d.). Seiring merajanya era digital yang ditandai munculnya berbagai platform aplikasi yang menyediakan dukungan pembuatan video dengan hal-hal yang menarik pada pengguna smartphone. Kini konten video sudah banyak tersebar di media sosial di berbagai negara dan juga di Indonesia. Pertumbuhan konten video sendiri dapat dengan mudah diunggah ke internet hal ini di dukung dengan kemajuan kecepatan internet. Banyak platform maupun aplikasi yang menyediakan dukungan pembuatan video dan dengan hal menarik pada pengguna smartphone. Salah satunya terdapat pada aplikasi Tik Tok yang berasal dari perusahaan teknologi asal Singapura, Bytemod, menghadirkan aplikasi edit video bernama "Tik Tok" (Susilowati 2018).

Aplikasi TikTok adalah sebuah jaringan sosial dan platform video musik Tiongkok yang diluncurkan pada September 2016. Aplikasi tersebut memperbolehkan penggunanya untuk membuat video music dengan durasi singkat (Wijaya 2020). Personal Branding adalah suatu proses ketika seseorang menggunakan dirinya atau karirnya sebagai merek (brand), memasarkan dirinya pada orang lain secara sistematis, sekaligus menarik persepsi publik secara aktif (Ruth and Candraningrum 2020). Karena pasar branding marketing pada aplikasi TikTok dinilai menjanjikan, tidak sedikit brand atau vendor ternama yang mencoba melakukan pemasaran melalui TikTok diantaranya seperti vendor brand smartphone berikut: Vivo, Oppo, Samsung, Realme dan Xiaomi. ("5 Brand HP Terlaris Di Indonesia Versi Canalys: Vivo Juara, Samsung Merosot | Kumparan.Com” n.d.).

Penelitian ini menggunakan metode eksploratif kuantitatif, dan akan menghitung menggunakan rasio-rasio yang ada pada TikTok. Penelitian ini hanya berfokus untuk menghitung kredibilitas Video Comments to Video Views Ratio pada 5 Brand HP Terlaris di Indonesia Versi Canalys. Tujuan dari penelitian ini adalah mengetahui kredibilitas performa dari akun TikTok 5 Brand HP Terlaris di Indonesia Versi Canalys menggunakan Video Comments to Video Views Ratio.

\section{TINJAUAN PUSTAKA}

Pada dewasa ini, sosial media menjadi sesuatu yang wajib disemua kalangan masyarakat. Tak hanya menjadi sesuatu yang wajib, faktanya sosial media menjadi suatu candu tersendiri di masyarakat untuk terhubung satu sama lain dengan bantuan teknologi yang semakin maju 
seperti saat ini. Beberapa aplikasi media sosial yang banyak digunakan oleh masyarakat saat ini antara lain adalah Facebook, Instagram, Twitter dan TikTok.

Berbagai media sosial, salah satunya Tiktok berkembang pesat dalam penggunaanya pada masyarakat (Fitrianti et al. 2021). Menurut (Luthan and Asmoro Putri 2021) Aplikasi TikTok sekarang ini menjadi sebuah trend sekaligus bukti adanya perkembangan teknologi yang membantu manusia dalam menjalankan aktivitasnya. Dikarenakan fitur For Your Page TikTok, para pengguna TikTok juga menggunakan fitur tersebut untuk mendongkrak popularitas untuk personal branding. Strategi yang digunakan setiap seleb TikTok dalam membentuk personal branding cenderung berbeda satu sama lain (Putri and Azeharie 2021).

Fenomena media sosial TikTok menjadi digital marketing, para pebisnis online tidak mau kalah untuk bersaing dalam memasarkan produknya, banyak sekali produk - produk dari online shop yang memasarkan produknya melalui disebut juga Influencer yang membuat konten berupa video untuk memasarkan dan memberikan informasi tentang produk seorang selebgram tidak hanya mereka yang memiliki latar belakang artis, namun hanya orang biasa yang memiliki penampilan dan gaya yang menarik yang terkenal (Fitri and Dwiyanti 2021).

Menurut penelitian (Sofyan 2020) menyatakan berdasarkan hasil penelitian Sensor Tower 2020 saat ini TikTok menjadi aplikasi media sosial dengan pertumbuhan yang pesat baik berdasarkan unduhan di Google Play Store maupun AppStore dan telah diunduh lebih dari 300 juta pengguna pada kuartal pertama dan kedua tahun 2020. Hal ini menunjukkan bahwa potensi digital marketing pada TikTok sangat besar dan tidak boleh dipandang remeh oleh perusahaanperusahaan yang ingin melakukan digital marketing untuk menarik lebih banyak peminat kepada produk-produknya.

TikTok dirasakan memiliki kekuatan ataupun pengaruh dalam industri, sehingga menimbulkan kualitas akun yang menentukan strata maupun kredibilitas pemilik akun. Kredibilitas akun TikTok merupakan suatu hal yang cukup penting untuk berbagai kepentingan. Kredibilitas sebuah akun TikTok dapat diukur dari tingkat performa yang dihasilkan secara matematis. Dalam mengukur performa diperlukan skala pengukuran yang tertuang ke dalam rasio. 


\section{METODE PENELITIAN}

Penelitian ini menggunakan teknik pengumpulan data dengan menggunakan metode eksplorasi kuantitatif. Penelitian eksploratif merupakan sebuah penelitian yang ingin menggali sesuatu hal yang baru, yang belum banyak diketahui oleh khalayak, sehingga ingin dikaji lebih dalam, biasanya menyangkut fenomena kontemporer, atau terkini (Mursitama n.d.). Sedangkan, Kuantitatif digunakan untuk meneliti populasi atau sampel dengan menggunakan alat ukur atau instrumen penelitian, analisa data bersifat kuantitatif atau statistik dengan tujuan menguji hipotesis yang telah dibuat (ITEBA 2021). Penelitian ini dilakukan untuk mengetahui kredibilitas pada 5 Brand Hp Terlaris Di Indonesia Versi Canalys.

Tujuan penelitian ini adalah untuk mengetahui kredibilitas dari kelima Brand Hp Terlaris Di Indonesia Versi Canalys melalui akun TikTok masing-masing brand tersebut. Untuk mengetahui brand yang memiliki kredibilitas paling tinggi, ada beberapa langkah yang harus dilakukan pada penelitian ini, diantaranya:

1. Melakukan Ekplorasi Website Untuk Menentukan Objek Yang Akan Dianalisa Menentukan objek yang akan dianalisa dan diteliti dengan melakukan ekplorasi terlebih dahulu pada beberapa halaman website yang menyediakan informasi terkait dengan objek yang akan diteliti. Setelah eksplorasi selesai dilakukan, langkah selanjutnya adalah memastikan 5 brand Hp tersebut memiliki akun sosial media TikTok dengan melakukan pengecekan satu per satu pada platform TikTok dengan mencari nama dari brand-brand Hp tersebut.

2. Menghitung Nilai Rata-Rata Variable Pada 5 Brand Hp Terlaris Di Indonesia Versi Canalys

Setelah tahap eksplorasi selesai dilakukan, maka pada tahap ini, akan dilakukan penghitungan variable video comments dan variable video views dengan cara mengambil 10 postingan dari masing-masing akun media sosial TikTok dari kelima brand Hp terkait kemudian dihitung sehingga menghasilkan nilai rata-rata untuk tiap variable yang dibutuhkan untuk menentukan kredibilitas paling tinggi.

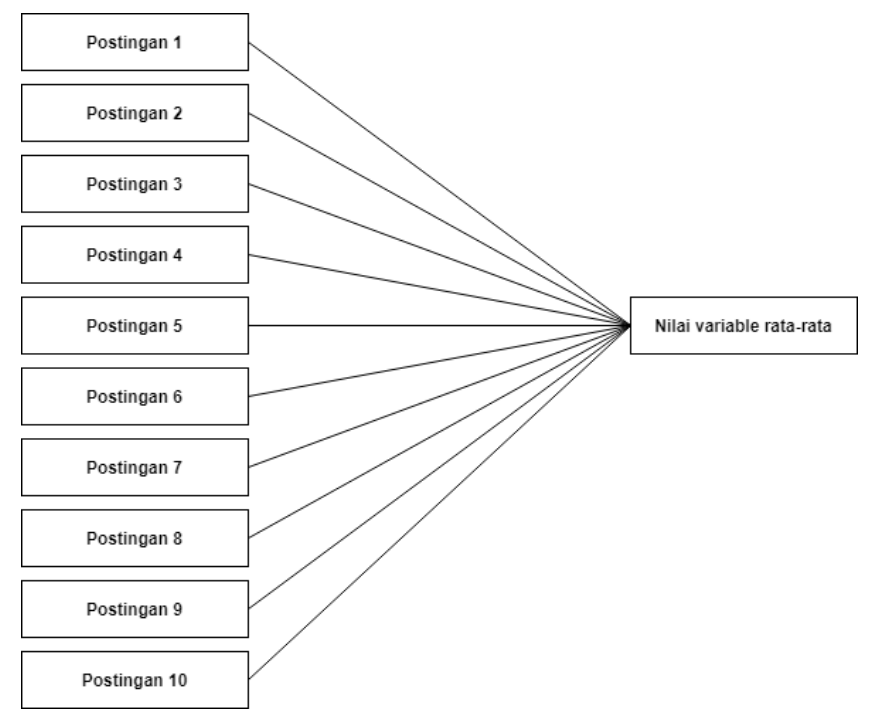

Gambar 1. Analisa Nilai Rata-Rata Variabel. 


\section{Menghitung Nilai Kredibilitas Rasio}

Setelah mengetahui nilai rata-rata untuk masing-masing variable, maka langkah selanjutnya adalah menghitung kredibilitas rasio video comments to video views dengan cara membagi nilai rata-rata variable 1 dengan nilai rata-rata variable 2 , pada kasus ini peneliti membagi nilai rata-rata variable video comments dengan nilai ratarata variable video views. Sebagai contoh apabila nilai rata-rata variable video comments adalah 10 dan nilai rata-rata variable video views adalah 8 , maka perhitungan yang dilakukan adalah $10 / 8=1.25$. sehingga nilai rasionya adalah 1.25.

\section{Menentukan Peringkat Pada Akun TikTok}

Ini adalah langkah terakhir yang dilakukan pada penelitian ini setelah menghitung nilai kredibilitas rasio video comments to video views pada kelima brand HP yang dijadikan objek penelitian. Untuk penentuan peringkat ini terdapat dua tipe penentuan peringkat berdasarkan karakteristik rasio yang diteliti. Pertama, apabila karakteristik rasio yang diperoleh adalah karakteristik tinggi, maka objek yang mendapatkan nilai tinggi akan mendapatkan angka 5 dan objek yang mendapatkan nilai terendah akan mendapatkan angka 1. Sebaliknya, apabila karakteristik rasio yang diperoleh merupakan karakteristik rendah, maka objek yang memiliki nilai terendah akan mendapatkan angka 5 dan objek yang memiliki nilai tertinggi akan mendapatkan angka 1. Setelah mendapatkan nilai kredibilitas rasio, maka dapat ditentukan objek mana yang mendapatkan peringkat 1 sampai dengan 5 . 


\section{HASIL DAN PEMBAHASAN}

Akun TikTok dari 5 Brand Hp Terlaris Di Indonesia Versi Canalys:

1. Vivo Indonesia

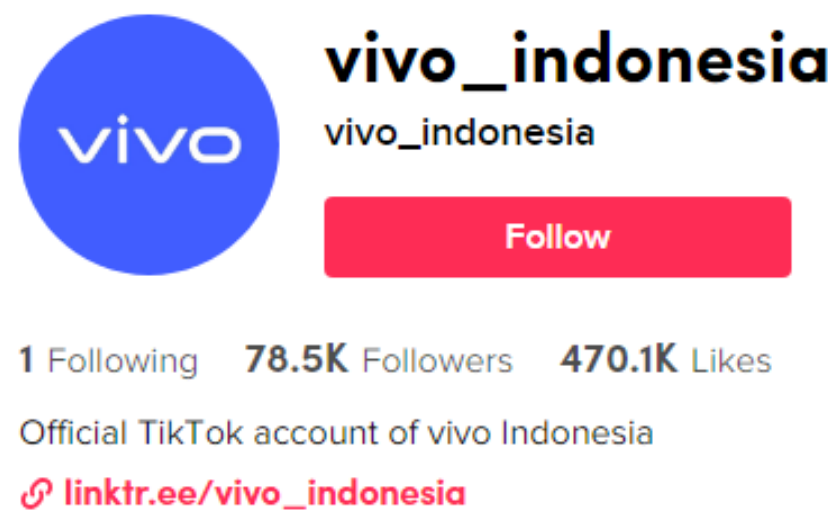

Gambar 1. Akun TikTok Vivo Indonesia

Sumber : https://www.tiktok.com/@vivo_indonesia (akses pada 14-10-2021)

\section{Oppo Indonesia}

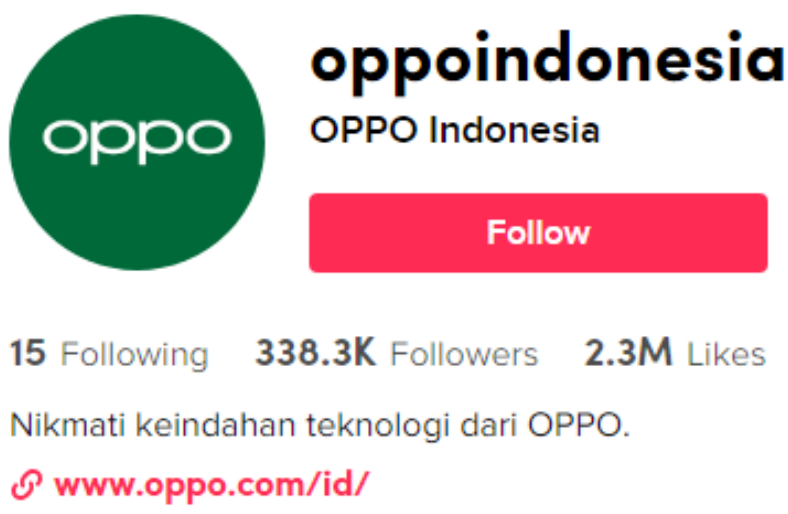

Gambar 2. Akun TikTok Oppo Indonesia

Sumber : https://www.tiktok.com/@ oppoindonesia (akses pada14-10-2021) 


\section{Xiaomi Indonesia}

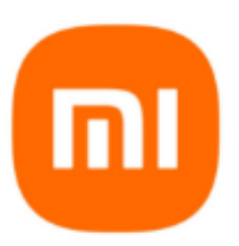

\section{xiaomi.indonesia}

Xiaomi Indonesia

\section{Follow}

33 Following $649.1 \mathrm{~K}$ Followers $3.6 \mathrm{M}$ Likes

Harga baru dari \#RedmiNote10S emang bikin kamu makin jawara, guys! klik link 1

$\mathcal{O}$ bit.ly/beliredminote10smicom

Gambar 3. Akun TikTok Xiaomi Indonesia

Sumber : https://www.tiktok.com/@xiaomi.indonesia (akses pada 14-10-2021)

\section{Realme Indonesia}

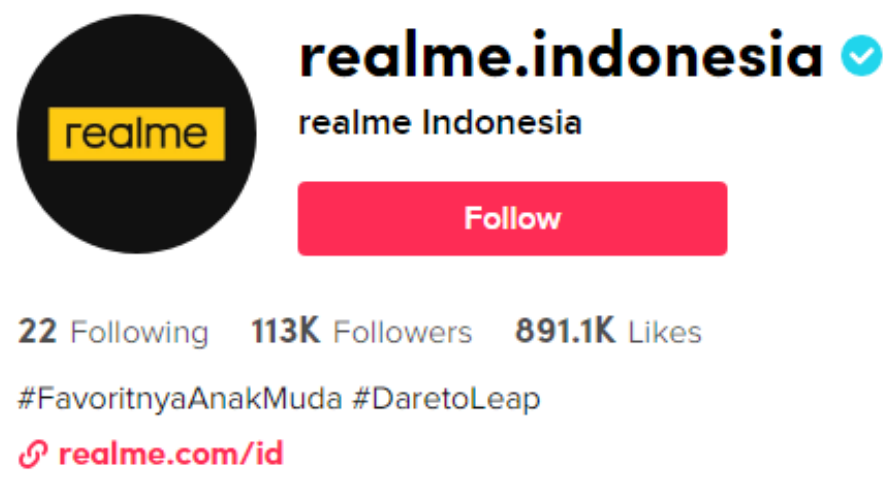

Gambar 4. Akun Tiktok Realme Indonesia

Sumber : https://www.tiktok.com/@realme.indonesia (akses pada 14-10-2021) 


\section{Samsung Indonesia}

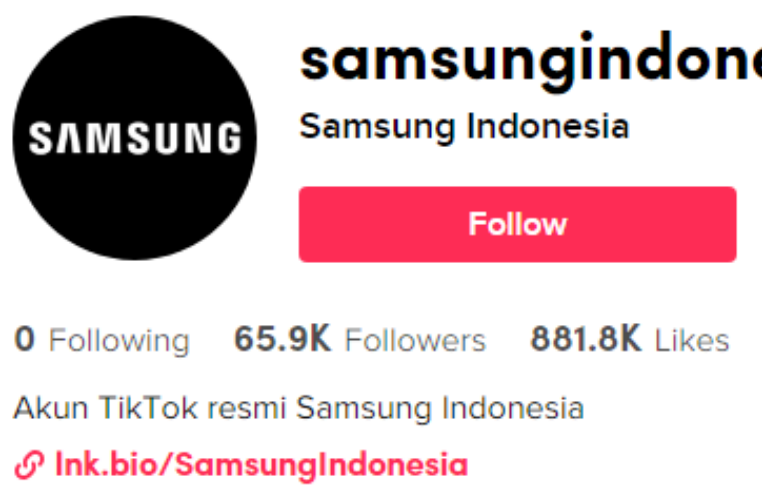

Gambar 5. Akun TikTok Samsung Indonesia

Sumber : https://www.tiktok.com/@samsungindonesia (akses pada 14-10-2021)

Dari kelima akun TikTok Brand Hp Terlaris Di Indonesia Versi Canalys, peneliti menemukan nilai dari masing-masing variabel yang ada untuk menghitung rasio Video Comments to Video Views dari setiap akun. Pada akun TikTok terdapat 7 variabel, diantaranya yaitu :

1. Likes

2. Followers

3. Following

4. Video Likes

5. Video Comments

6. Video Share

7. Video Views

Dari ketujuh variabel tersebut peneliti hanya fokus untuk menemukan hasil dari 2 variabel, yaitu :

1. Video Comments

2. Video Views

Dari kedua variabel tersebut kemudian dianalisa sehingga menemukan nilai rata-rata dari variabel video comments dan variabel video views. Untuk menghitung nilai rata-rata dari variabel video comments dan variabel video views yaitu dengan cara mengambil minimal 10 postingan kemudian di hitung sehingga menemukan nilai rata-rata dari masing-masing variabel. Berikut merupakan tabel nilai rata-rata dari masing-masing vendor smartphone di Indonesia, yaitu : 
Tabel 1. Analisa Nilai Rata-Rata Nilai Variabel Video Comments dan Video Views Akun TikTok Vivo Indonesia

\begin{tabular}{|c|c|c|}
\hline NO & Video Comments & Video Views \\
\hline 1 & 167 & 21.400 \\
\hline 2 & 11 & 12.000 \\
\hline 3 & 6 & 7.772 \\
\hline 4 & 1 & 6.563 \\
\hline 5 & 12 & 7.929 \\
\hline 6 & 81 & 2.100 .000 \\
\hline 7 & 49 & 1.600 .000 \\
\hline 8 & 11 & 6.352 \\
\hline 9 & 18 & 5.701 \\
\hline 10 & 2 & $\mathbf{7 9 6 . 7 7 2}$ \\
\hline Total & $\mathbf{3 6}$ & \\
\hline
\end{tabular}

Sumber : Pengolah Data Excel

Tabel 2. Analisa Nilai Rata-Rata Nilai Variabel Video Comments dan Video Views Akun TikTok Oppo Indonesia

\begin{tabular}{|c|c|c|}
\hline NO & Video Comments & Video Views \\
\hline 1 & 10 & 3.739 \\
\hline 2 & 172 & 4.500 .000 \\
\hline 3 & 22 & 9.319 \\
\hline 4 & 14 & 14.900 \\
\hline 5 & 2 & 5.484 \\
\hline 6 & 14 & 10.600 \\
\hline 7 & 6 & 7.613 \\
\hline 8 & 13 & 10.800 \\
\hline
\end{tabular}




\begin{tabular}{|c|c|c|}
9 & 29 & 2.300 .000 \\
\hline 10 & 27 & 2.300 .000 \\
\hline Total & $\mathbf{3 1}$ & $\mathbf{9 1 6 . 2 4 6}$ \\
\hline
\end{tabular}

Sumber : Pengolah Data Excel

Tabel 3. Analisa Nilai Rata-Rata Nilai Variabel Video Comments dan Video Views Akun TikTok Xiaomi Indonesia

\begin{tabular}{|c|c|c|}
\hline NO & Video Comments & Video Views \\
\hline 1 & 14 & 2.061 \\
\hline 2 & 27 & 145.100 \\
\hline 3 & 15 & 2.859 \\
\hline 4 & 27 & 60.500 \\
\hline 5 & 28 & 2.884 \\
\hline 6 & 3 & 2.648 \\
\hline 7 & 15 & 153.700 \\
\hline 8 & 29 & 2.750 \\
\hline 9 & 8 & 2.818 \\
\hline 10 & 7 & $\mathbf{6 7 . 0 1 2}$ \\
\hline Total & $\mathbf{1 7}$ & \\
\hline
\end{tabular}

Sumber : Pengolah Data Excel

Tabel 4. Analisa Nilai Rata-Rata Nilai Variabel Video Comments dan Video Views Akun TikTok Realme Indonesia

\begin{tabular}{|c|c|c|}
\hline NO & Video Comments & Video Views \\
\hline 1 & 21 & 44.500 \\
\hline 2 & 15 & 9.560 \\
\hline 3 & 26 & 54.900 \\
\hline 4 & 9 & 1.000 .000 \\
\hline 5 & 16 & 826.100 \\
\hline
\end{tabular}




\begin{tabular}{|c|c|c|}
6 & 14 & 898.100 \\
\hline 7 & 51 & 690.500 \\
\hline 8 & 57 & 582.200 \\
\hline 9 & 20 & 549.800 \\
\hline 10 & 17 & 462.700 \\
\hline Total & $\mathbf{2 5}$ & $\mathbf{5 1 1 . 8 3 6}$ \\
\hline
\end{tabular}

Sumber : Pengolah Data Excel

Tabel 5. Analisa Rata-Rata Nilai Variabel Video Comments dan Video Views Akun TikTok Samsung Indonesia

\begin{tabular}{|c|c|c|}
\hline NO & Video Comments & Video Views \\
\hline 1 & 5 & 374 \\
\hline 2 & 2 & 437 \\
\hline 3 & 2 & 501 \\
\hline 4 & 5 & 3.500 .000 \\
\hline 5 & 76 & 1.458 \\
\hline 6 & 4 & 2.401 \\
\hline 7 & 75 & 3.600 .000 \\
\hline 8 & 74 & 3.600 .000 \\
\hline 9 & 116 & 3.700 .000 \\
\hline 10 & 36 & $\mathbf{1 . 4 4 0 . 6 0 3}$ \\
\hline Total & & \\
\hline
\end{tabular}

Sumber : Pengolah Data Excel 
Setelah menghitung nilai rata-rata tersebut, maka akan menemukan hasil akhir nilai rata-rata dari variabel video comments dan variable video views

Tabel 6. Nilai Variabel Pada 5 Brand Hp Terlaris Di Indonesia Versi Canalys

\begin{tabular}{|c|c|c|c|c|c|}
\hline Variable & $\begin{array}{c}\text { vivo_indon } \\
\text { esia }\end{array}$ & $\begin{array}{c}\text { oppoindon } \\
\text { esia }\end{array}$ & $\begin{array}{c}\text { xiaomi.indon } \\
\text { esia }\end{array}$ & $\begin{array}{c}\text { realme.indon } \\
\text { esia }\end{array}$ & $\begin{array}{c}\text { samsungindon } \\
\text { esia }\end{array}$ \\
\hline $\begin{array}{c}\text { Video } \\
\text { Commen } \\
\text { ts }\end{array}$ & 36 & 31 & 17 & 25 & 36 \\
\hline $\begin{array}{c}\text { Video } \\
\text { Views }\end{array}$ & 796772 & 916246 & 67012 & 511836 & 1440603 \\
\hline
\end{tabular}

Sumber : Pengolah Data Excel

Pada akun TikTok terdapat 17 rasio yang relevan digunakan untuk mengukur kredibilitas pada masing-masing akun. Namun pada penelitian kali ini hanya berfokus untuk menghitung Video Comments to Video Views Ratio. Untuk menghitung kredibilitas dari masing-masing akun TikTok setiap vendor smartphone, peneliti menghitung dengan cara : variabel 1 akan dibagi dengan variabel 2 , sehingga ditemukan hasil analisisa dari rasio tersebut.

Tabel 7. Hasil Perhitungan Rasio Akun TikTok

\begin{tabular}{|l|c|c|c|c|c|}
\hline \multicolumn{1}{|c|}{ Ratio } & $\begin{array}{c}\text { vivo_indone } \\
\text { sia }\end{array}$ & $\begin{array}{c}\text { oppoindone } \\
\text { sia }\end{array}$ & $\begin{array}{c}\text { xiaomi.indon } \\
\text { esia }\end{array}$ & $\begin{array}{c}\text { realme.indon } \\
\text { esia }\end{array}$ & $\begin{array}{c}\text { samsungindon } \\
\text { esia }\end{array}$ \\
\hline Video & 0,00004493 & 0,00003372 & 0,00025816 & 0,00004806 & 0,00002527 \\
Comme & & & & & \\
nts to & & & & & \\
Video & & & & & \\
Views & & & & & \\
\hline
\end{tabular}

Sumber : Pengolah Data Excel

Video Comments to Video Views Ratio memiliki karakteristik yang tinggi, artinya semakin tinggi nilai yang dihasilkan maka semakin baik kredibilitas dari performa akun tersebut. Untuk memberikan peringkat pada masing-masing Vendor Smartphone, peneliti memberikan angka 5 kepada vendor yang mendapatkan nilai tertinggi dan angka 1 untuk vendor smartphone yang mendapatkan nilai terendah. Berikut merupakan tabel urutan nilai yang dihasilkan oleh masingmasing vendor smartphone. 
Tabel 8. Nilai Rasio Akun TikTok 5 Brand Hp Terlaris Di Indonesia Versi Canalys

\begin{tabular}{|c|c|}
\hline vivo_indonesia & 3 \\
\hline oppoindonesia & 2 \\
\hline xiaomi.indonesia & 5 \\
\hline realme.indonesia & 4 \\
\hline samsungindonesia & 1 \\
\hline
\end{tabular}

Sumber : Pengolah Data Excel

Dari Tabel Nilai Rasio Akun TikTok 5 Brand Hp Terlaris Di Indonesia Versi Canalys dapat simpulkan bahwa Xiaomi Indonesia mendapatkan nilai tertinggi untuk rasio Video Comments to Video Views. Sedangkan akun TikTok Samsung Indonesia mendapatkan nilai terendah untuk rasio ini. Jadi, pada penelitian ini Xiaomi Indonesia memiliki kredibilitas performa yang lebih baik dibandingkan dengan vendor smartphone yang lainnya.

\section{KESIMPULAN}

Tujuan dari penelitian ini adalah mengetahui kredibilitas performa dari akun TikTok 5 Brand Hp Terlaris Di Indonesia Versi Canalys menggunakan Video Comments to Video Views Ratio. Top 5 Vendor Smartphone tersebut diantaranya : Vivo Indonesia, Oppo Indonesia, Xiaomi Indonesia, Realme Indonesia dan Samsung Indonesia. Dari kelima vendor smartphone tersebut dapat disimpulkan bahwa :

1. Peringkat pertama diraih oleh vendor Xiaomi Indonesia dengan nilai tertinggi yaitu 0,00025816

2. Peringkat kedua diraih oleh vendor Realme Indonesia dengan nilai 0,00004806

3. Peringkat ketiga diraih oleh vendor Vivo Indonesia dengan nilai 0,00004493

4. Peringkat keempat diraih oleh vendor Oppo Indonesia dengan nilai 0,00003372

5. Peringkat kelima diraih oleh vendor Samsung Indonesia dengan nilai terendah yaitu 0,00002527 


\section{DAFTAR PUSTAKA}

"5 Brand HP Terlaris Di Indonesia Versi Canalys: Vivo Juara, Samsung Merosot | Kumparan.Com.” n.d. Accessed October 28, 2021. https://kumparan.com/kumparantech/5-brand-hp-terlaris-di-indonesia-versi-canalysvivo-juara-samsung-merosot-1v9mNsGxcRI/1.

Eka Putri, Ni Luh Wiwik. 2009. "Interaksi Simbolik Dalam Proses Komunikasi Nonverbal Pada Aplikasi Tiktok." Widya Duta: Jurnal Ilmiah Ilmu Agama Dan Ilmu Sosial Budaya 14 (1): 11. https://doi.org/10.25078/wd.v14i1.1039.

Fitri, Afriza Indah, and Selvi Ainul Inayah Dwiyanti. 2021. "Efektivitas Media Tiktok Dan Influencermendongkrak Penjualan Lippie Serum Raeccadipandemi Covid19." Jurnal Ekonomi Dan Bisnis (EK\&BI) 4 (1): 345-53. https://doi.org/10.37600/ekbi.v4i1.210.

Fitrianti, Ayang, Errika Dwi, Setya Watie, and Firdaus Azwar Ersyad. 2021. "Personal Branding Mahasiswa Ilmu Komunikasi USM Geri Da Pinto Pada Akun Creator TikTok @OMAGAAAKKK.” Dinamika Sosial Budaya 23 (1): 10-21. http://journals.usm.ac.id/index.php/jdsb.

ITEBA. 2021. "Perbedaan Penelitian Kualitatif, Kuantitatif, Dan Gabungan - ITEBA.” 2021. https://iteba.ac.id/blog/perbedaan-metode-penelitian-kualitatif-kuantitatif-gabungan/.

Luthan, Asia Khairunnisa, and Zahira Xenia Asmoro Putri. 2021. "Fenomenologi Aplikasi Tiktok Bagi Usaha Online Marica Farms.” Kinesik 8 (2): 128-36. https://doi.org/10.22487/ejk.v8i2.153.

Mursitama, Tirta. n.d. "TUJUAN PENELITIAN: Eksploratif, Deskriptif, Eksplanatif Dan Evaluatif - YouTube.” Accessed November 13, 2021. https://www.youtube.com/watch?v=TYXnkyjfsJo.

Putri, Shani Dwi, and Suzy Azeharie. 2021. "Strategi Pengelolaan Komunikasi Dalam Membentuk Personal Branding Di Media Sosial Tiktok.” Koneksi 5 (2): 280. https://doi.org/10.24912/kn.v5i2.10300.

Ruth, Debra, and Diah Ayu Candraningrum. 2020. "Pengaruh Motif Penggunaan Media Baru Tiktok Terhadap Personal Branding Generasi Milenial Di Instagram.” Koneksi 4 (2): 207. https://doi.org/10.24912/kn.v4i2.8093.

Sofyan. 2020. "Jurnal Ekonomi, Manajemen, Bisnis Dan Sosial.” Jurnal Ekonomi, Manajemen, Bisnis Dan Sosial Available 1 (46): 34-39.

Susilowati. 2018. "Pemanfaatan Aplikasi Tiktok Sebagai Personal Branding Di Instagram." Jurnal Komunikasi 9 (2): 176-85. https://ejournal.bsi.ac.id/ejurnal/index.php/jkom/article/viewFile/4319/2703.

Wijaya, Mukhammad. 2020. "Konsumsi Media Sosial Bagi Kalangan Pelajar.” Jurnal Agama Sosial Dan Budaya 3 (2): 170-92. 